\title{
急勾配斜面の崩壊発生機構に関する実験的研究*
}

\section{Experimental Study on a Mechanism of the Steep Slope Failure}

\author{
笹 原 克 夫** 海老原 和 重** 綱 木 亮 介** \\ Katsuo SASAHARA Kazushige EBIHARA \\ Ryousuke TsUNAKI
}

\begin{abstract}
In order to examine the mechanism of the collapse of steep unsaturated slope, 2 types of experiments were carried out. One is the series of the laboratory model experiments of sandy steep slope failure caused by artificial rainfall. Another is the series of triaxial compression tests of the sandy soil under different saturation ratios.

As the results of these experiments, deformation characteristics of unsaturated soil mentioned below have been made clear.

(1) The basic relationship between shear strain of the unsaturated soil and saturation ratio is hyperbolic. If the saturation ratio becomes larger, the shear strain becomes larger.

(2) If the normal stress becomes larger, the hyperbolic curve of the laboratory tests between the shear strain and the saturation ratio moves to the higher saturation ratio region. But, on the contrary, the relationship curve of the triaxial compression tests moves to the lower saturation ratio region if the confining stress becomes larger.
\end{abstract}

(3) In the laboratory tests, the relationship between shear strain and saturation ratio moves to lower saturation ratio region if the surface slope gradient becomes larger. This result of laboratory tests coincides with the fact that shear strain proceeds in the lower saturation ratio region if the stress ratio becomes larger. キーワード: 斜面崩壊*, 不飽和土, せん断ひずみ*, 模型実験, 三軸圧縮試験

\section{1.はじめに}

平成 5 年 7〜9 月の鹿児島災害では, $40 \sim 60^{\circ}$ 程度の急 勾配のり面・斜面に崩壊が多発した ${ }^{1)}$ 。崩壊した切土のり 面の多くは勾配 $60^{\circ}$ 以上であり，また崩壊した自然斜面 でも，特に高度差の大きな斜面は勾配が大きく, $60^{\circ}$ から $90^{\circ}$ 近くあるものもあった。また過去に「がけ崩れ」とし て報告のあった斜面でも $77.1 \%$ が $40^{\circ}$ 以上の斜面で発生 している2。ここれちみると，のり面・斜面崩壊対策を考 える上で, 勾配が $40^{\circ}$ 程度以上ある急勾配のり面・斜面の 対策や予知・予測が重要であることがわかる。

過去の人工降雨による崩壊実験の事例を見ると, すべ り面が地下水位より浅い場所に形成されている3(4) か, ま たは地下水位が発生しない状態で崩壊が発生しているも の) がある。この現象は, 崩壊が地下水位の上昇による有 効応力の減少により発生するとする従来の理論では説明

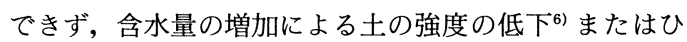
ずみの進行というような不飽和状態での崩壊発生機構を

\footnotetext{
* なお, 本論文の一部は平成 6 年度砂防学会研究発表会及び第 33 回地すべり学会研究発表会で発表した。

** 建設省土木研究所
}

\section{考える必要がある。}

本論文では, 以上の知見を踏まえ, 急勾配斜面の不飽 和状態での崩壊発生機構を解明するための第一歩として, 砂質土斜面の人工降雨による崩壊実験を行い, 地中変位 量と地中水分量の関係について解析を行った。またその 結果を, 不飽和状態の試料土の三軸圧縮試験結果と比較 し, 急勾配斜面の不飽和状態における崩壊発生機構を, 不飽和土の変形・破壊特性から説明することを試みた。

\section{2 . 急勾配斜面の崩壊実験}

\section{1 実験の種類と方法}

不飽和状態の急勾配斜面内の, 降雨時における地中変 位量と地中水分量の関係を調べるために, 砂質土の模型 斜面を作成し，人工降雨による崩壊実験を行った。

実験は以下の 2 種類行った。なお，模型斜面を作成し た試料土の土粒子の密度は $2.702\left(\mathrm{~g} / \mathrm{cm}^{3}\right)$ であり，その 粒径分布は図一 1 の通りである7)。

(1)実験 $1(\text { 図 }-2(a))^{7)}$

表面勾配を $40^{\circ}$ とし, 降雨強度 $120 \mathrm{~mm} / \mathrm{h}$ を崩壊 発生まで継続した。

(2)実験 2(図-2(b)) $)^{8)}$ 


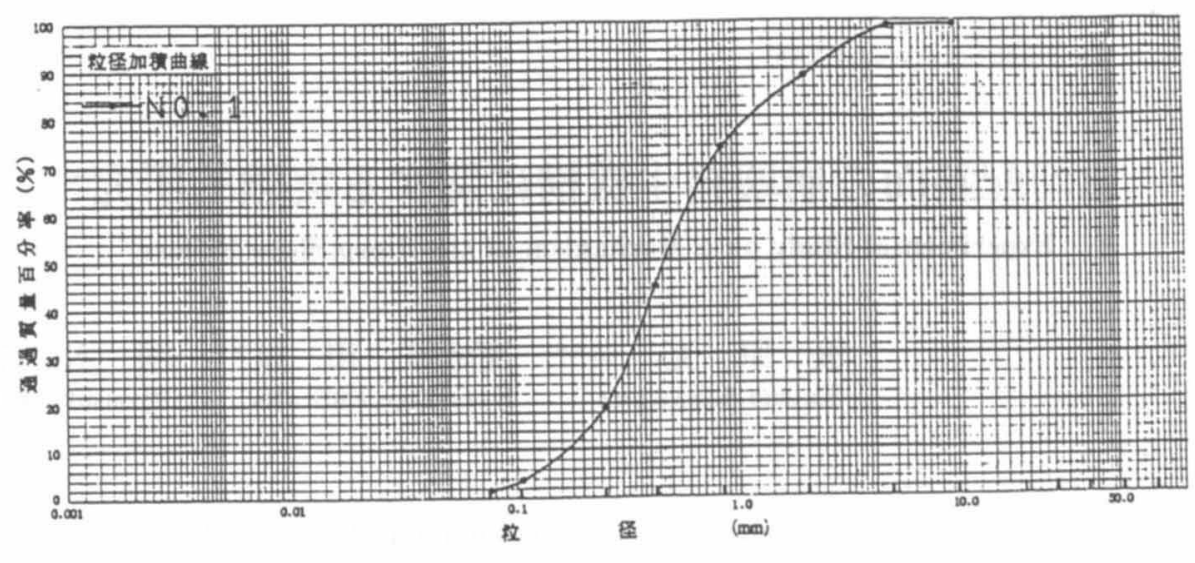

図-1 試料土の粒径加積曲線

Fig. 1 Particle size accumlation curve of the soil used in the experiment

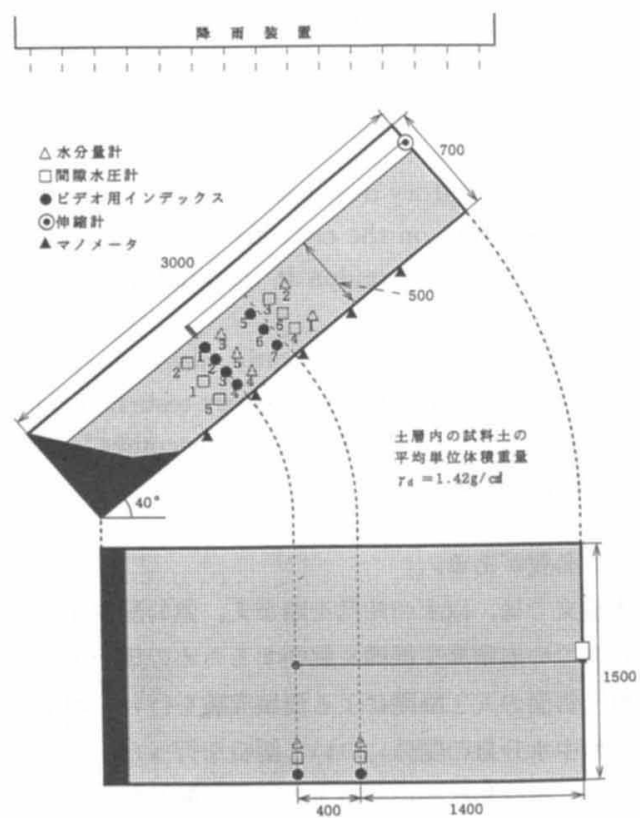

(a) 実験 1

(a) Experiment No. 1

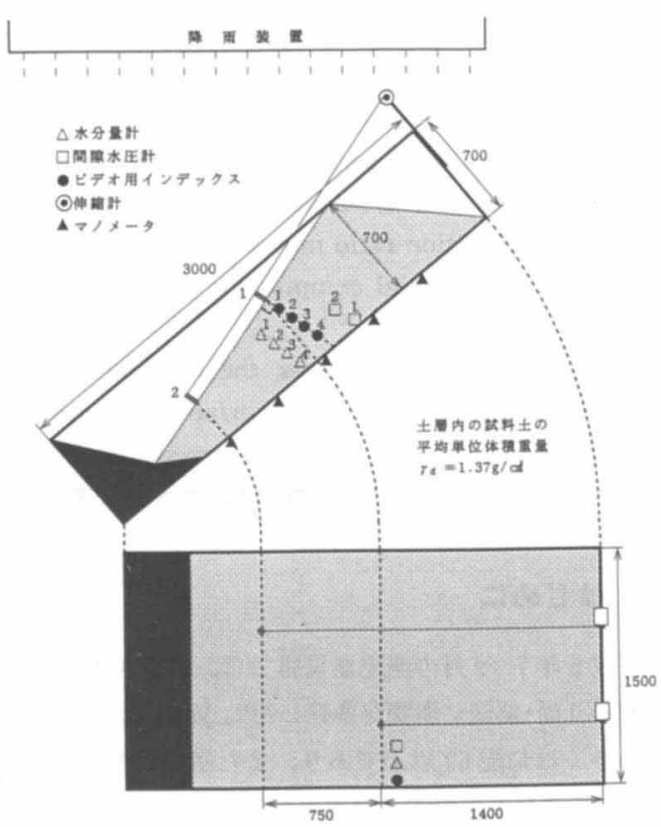

(b) 実験 2

(b) Experiment No. 2

図-2 実験装置と斜面形状

Fig. 2 The experimental facility and the shape of slope

表面勾配を $55^{\circ}$ とし, 降雨強度を実験開始後 90 分 まで $40 \mathrm{~mm} / \mathrm{h}, 90$ 分から 150 分まで $50 \mathrm{~mm} / \mathrm{h}$, その 後崩壤発生まて $70 \mathrm{~mm} / \mathrm{h}$ とした。

実験装置本体は鋼製であるが, 側壁は強化ガラスであ るのて側面からの観察が可能である。また斜面下端は排 水条件となるように, 多数の排水孔が設けてある。図一 2 中のピデオ用インデックスは直径 $6 \mathrm{~mm}$ の白色の短棒 であり,模型斜面側面に配置した。地中変位量とインデッ クス変位量は等しいと仮定して, ビデオで追跡したイン デックスの変位をその位置における地中変位とした。水
分量計は坂田電気 侏製作の $\mathrm{RX}-2254$ 型であり, 4 電極 インピーダンス測定方式のものである。計測項目は地表 面変位 (伸縮計), 地中変位 (ピデオ用インデックス), 土中体積含水率 (水分量計), 地下水位 (間隙水圧計, マ ノメータ) である。

模型斜面の作成は実験装置を水平にして, 層厚 $10 \mathrm{~cm}$ 毎に人力踏み固めを行って作成した。作成中及び完成後 に不摫乱サンプルを採取し, その単位体積重量を計測し て, 斜面が均一に踏み固められていることを確認した。 また実験 2 の斜面形状については, 実験装置の底面勾配 
の上限が $40^{\circ}$ であるが，表面勾配をより大きくするため

に, 底面勾配と表面勾配を変化させた。

\section{2 崩壊実験結果}

(1) 実験 $1^{7)}$

まず斜面上端から $1800 \mathrm{~mm}$ 付近の, 地表面に垂直方 向の体積含水率分布と累積地表・地中変位量の経時的変 化を図-3に示す。この図より地下水位より浅い位置で も(つまり不飽和状態でも), ある程度の体積含水率にな ると地中変位が発生することがわかる。

次に斜面内の土のせん断変位の状況をより詳しく見る
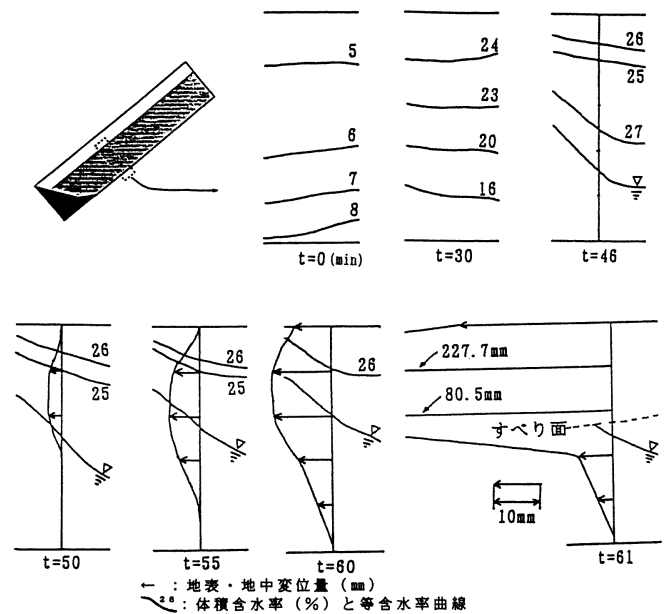

図ー3 実験 1 における $L=1800 \mathrm{~mm}$ での土中体積含水率と 地表・地中変位量

Fig. 3 The distribution of the water (volumetric) content and the shear displacement in the slope at $L=1800$ $\mathrm{mm}$ in the experiment No. 1
ために, 図ー3 と同じ測線上の, ビデオ用インデックス間 のせん断ひずみと飽和度, 地下水位の関係を図-4に示 す。ここで飽和度は図-3よりインデックス間の平均值 を求め, インデックス間のせん断ひずみは図 -5 に示す インデックス間の変位量をインデックス間の距離で除し た值とし，インデックス間の地下水位も図 -5 の定義に 従った。図一 4 を見ると最も梁い $30 \sim 40 \mathrm{~cm}$ の位置で変 位量が大きい場合を除いて，インデックス間に地下水位 が発生することなく, 不飽和状態でせん断変位が進行し ていることがわかる。この図では, 必ずしもせん断変位 が正の方向に増加し続けているわけではなく，飽和度の 上昇と共にせん断変位が負の方向に生じている場合もあ

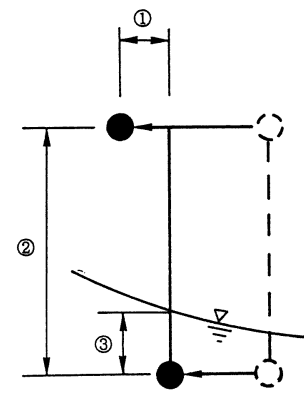

\section{(1)インデックス間の変位桌 (2)インデックス間の距離} (3)インデックス間の地下水位

(1)については、上のインテックスの方が 果積変位が大きい場合を正とする

图ー5 インデックス間のせん断ひずみと地下水位

Fig. 5 Definition of shear strain and water level between the video indexes
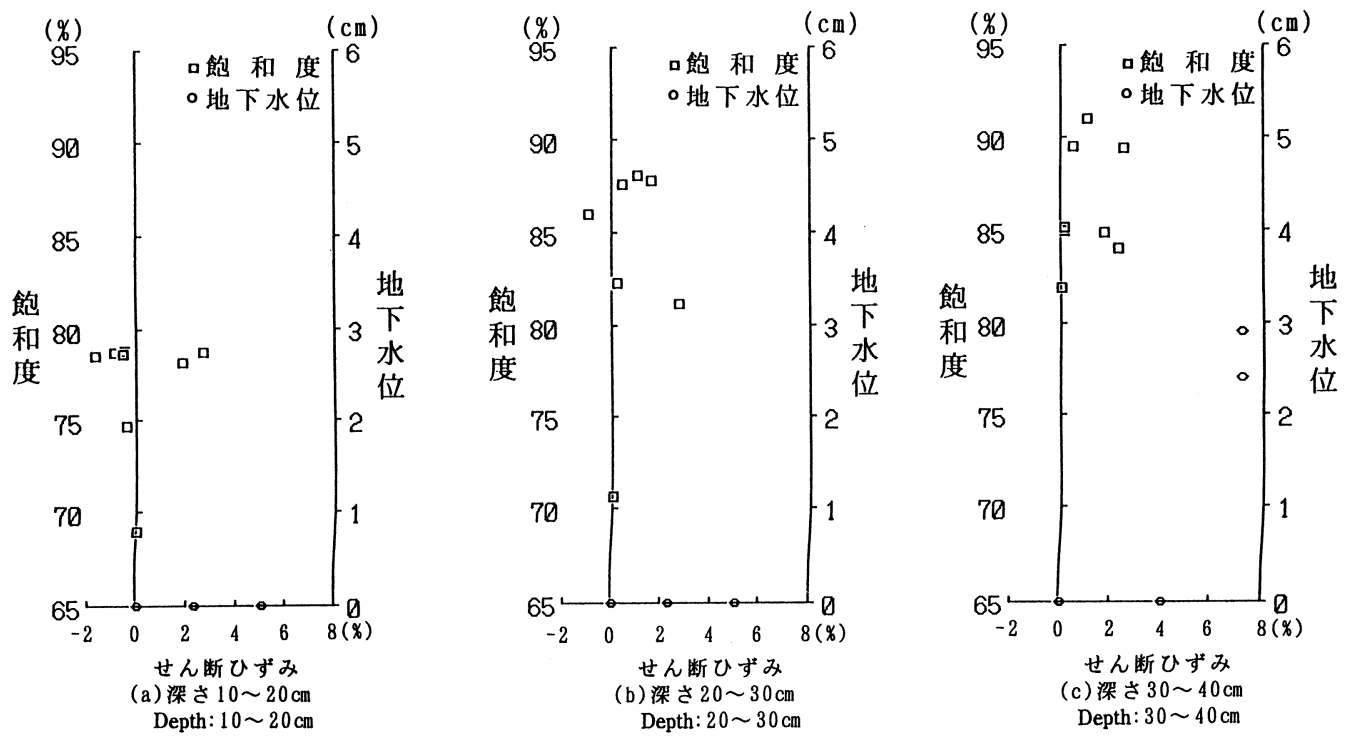

图ー4 実験 1 における $L=1800 \mathrm{~mm}$ での地中のせん断ひずみ一飽和度，地下水の関係

Fig. 4 Relationships between shear strain and saturation ratio, water level at $L=1800 \mathrm{~mm}$ in the experiment No. 1 
る。これはこの断面においてせん断がやや不連続かつ不 均一に進行しているため, 常に土層深が小さいほどせん 断の進行が大きいわけではないためと考えられる。

(2)実験 $2^{8)}$

実験 2 について，斜面上端から $1400 \mathrm{~mm}$ の位置での， 地表面に垂直方向の体積含水率分布と累積地表・地中変 位量の経時的変化を図一 6 に, また斜面内のインデック ス間のせん断ひずみと飽和度の関係を図ー7 に示す。
図一6 を見ると実験 1 の場合と同様に，基本的に不飽 和状態でせん断が進行している。また土層深が小さい程, 地中変位の発生が早くなり, かつ累積地中変位が大きく なることもわかる。図 -7 より実験 2 では実験 1 より小 さい飽和度でせん断が進行していることがわかる。

\section{3 考 察}

以上 2 種類の実験結果，特に斜面中のせん断ひずみと 飽和度の関係を表す図 $-4,7$ より，以下の解析を行った。

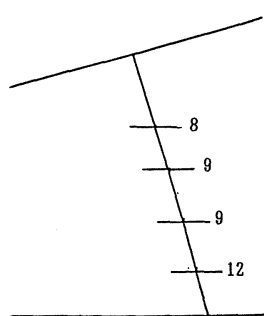

$t=0$ (min)

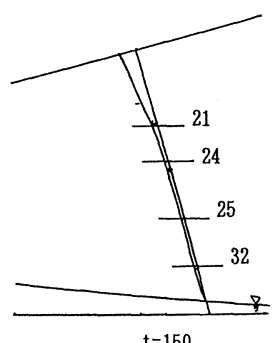

$\mathrm{t}=150$

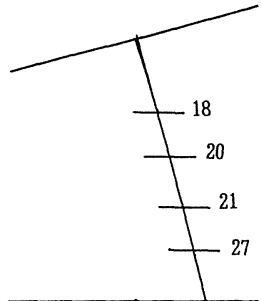

$\mathrm{t}=90$

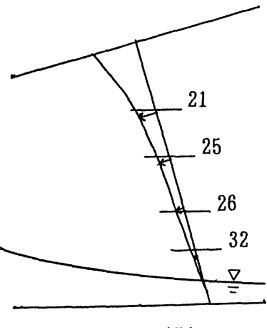

$t=154$

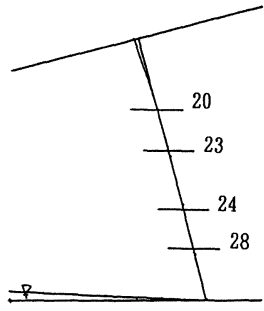

$t=120$

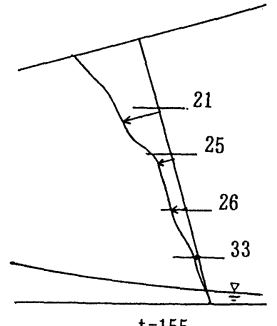

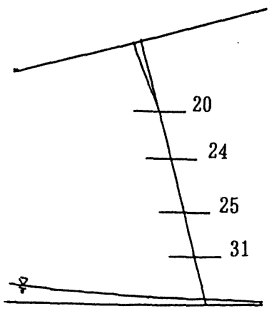

$t=140$

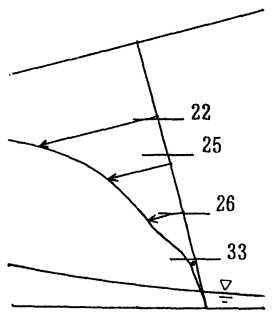

$t=155$

$\mathrm{t}=156$

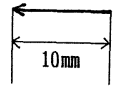

$\leftarrow$ : 地表・地中变位量 (凅)

息: 体樌含水率 $(\%)$ と等含水率曲線

図ー6 実験 2 における $L=1400 \mathrm{~mm}$ での土中体積含水率と地中変位量

Fig. 6 The distribution of the water (volumetric) content and the shear displacement in the slope at $L=1400$ $\mathrm{mm}$ in the experiment No. 2
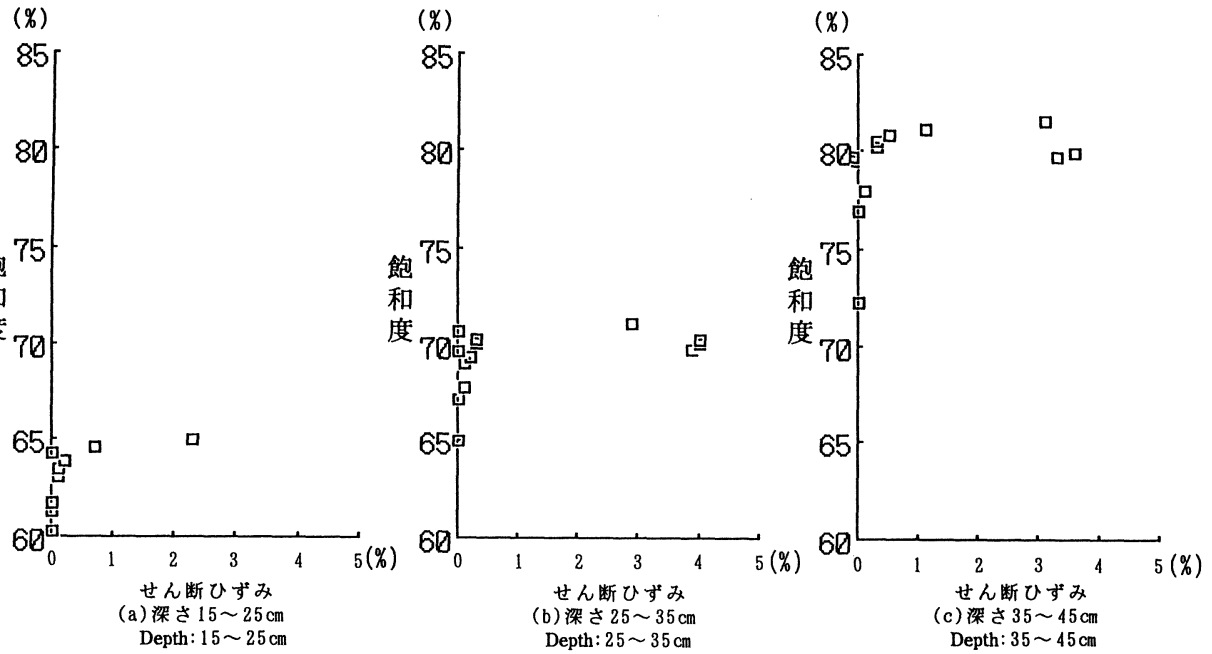

図ー7 実験 2 における $L=1400 \mathrm{~mm}$ での地中のせん断ひずみ一飽和度の関係

Fig. 7 Relationships between shear strain and saturation ratio at $L=1400 \mathrm{~mm}$ in the experiment No. 2 
(1)せん断ひずみ一飽和度

既に実験 1 については図一 4 に，また実験 2 について は図-7に, 各深さのせん断ひずみ一飽和度の関係を示 している。図ー4ではそれほど明瞭ではないが, 図一7で は飽和度の上昇と共に微少ではあるがせん断ひずみが大 きくなり，ある飽和度に近づくにつれてせん断ひずみが 無限大になるような, 双曲線関係が両者の間に認められ る。

(2)垂直応力が変化した時のせん断ひずみ一飽和度

図-8 は実験 2 について，各深さのせん断ひずみ一飽 和度を重ねて比較できるようにしている。これを見ると 深い位置の方が，言い換えれば垂直応力が大きい位置で の方が，飽和度が大きい状態でせん断が進行しているこ とがわかる。

(3)傾斜が大きくなった時のせん断ひずみ一飽和度 地表面勾配の異なる実験 1,2 における, 最も浅い位置 のインデックスとその下のインデックスの間の, せん断 ひずみ一飽和度の関係を図ー9に重ねて示す。地表面勾 配の小さな実験 1 (勾配 $40^{\circ}$ ) の方がやや浅い位置のせん 断ひずみを表しているが，図一8より導かれる結論を考 えると，これが実験 2 (勾配 $55^{\circ}$ ) と等しい深さにあれば より大きな飽和度でせん断が進行することになる。この ことより地表面勾配が大きい方が小さな飽和度の下でせ ん断が進行することがわかる。

\section{3 ．不飽和試料の三軸圧縮試験}

\section{1 試験条件}

上記の崩壊実験で確認された，飽和度上昇による土の せん断変形の進行過程, 特に崩壊実験では認識が困難な 微少ひずみ段階の進行を明確な応力・ひずみ状態の実験 で確認するために，飽和度の異なる試料のひずみ制御方 式の三軸圧縮試験結果と比較・検討する。

三軸圧縮試験は側圧一定の圧密排水条件で行い, 飽和 度の異なる 5 種類の試料に対して行った。また一つの飽 和度の試料につき，側圧を 4 種類変化させて行った。試 験条件を表一 1 に示す。各試験はせん断ひずみが $15 \%$ に 達した時点で終了した9)。試料は崩壊実験で使用したも のを用い，供試体作成後の間隙比を一定とした。

\section{2 解 析}

表－1の条件の試験結果より，図-10 では各飽和度， 各側圧の応力ひずみ曲線から応力比 $z=1.2$ 及び 1.5 の 時の $\varepsilon_{1}$ と $\varepsilon_{3}$ を読みとってせん断ひずみを求め，異なる 側圧下でのせん断ひずみと飽和度の関係を求めた。同様 に図-11では各飽和度の側圧 $\sigma_{3}=0.2,0.4\left(\mathrm{kgf} / \mathrm{cm}^{2}\right)$ の時の応力ひずみ曲線から応力比が $0.43,0.75,1.2$, $1.5,1.52$ の時の $\varepsilon_{1}$ と $\varepsilon_{3}$ を読みとってせん断ひずみを 求め, 異なる応力比でのせん断ひずみと飽和度の関係を

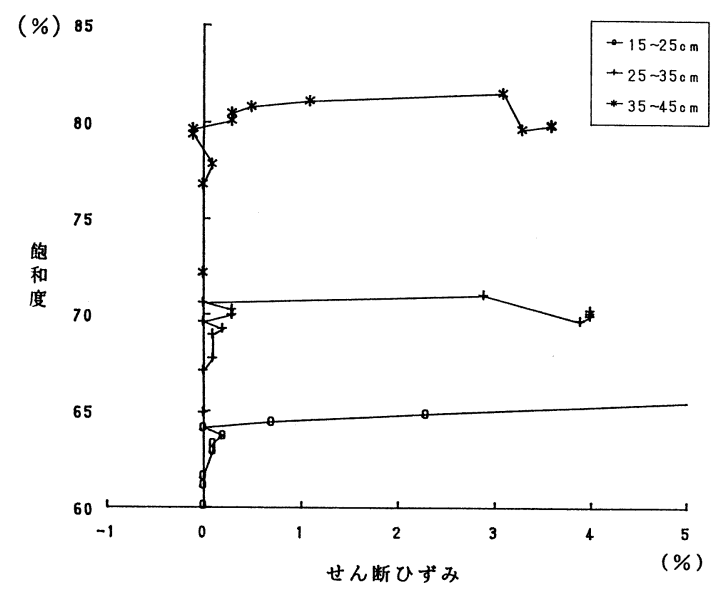

图ー8 深さの異なる場合のせん断ひずみ一飽和度 (実験 2)

Fig. 8 Comparison of the relationships between shear strain and saturation ratio under different depth in the experiment No. 2

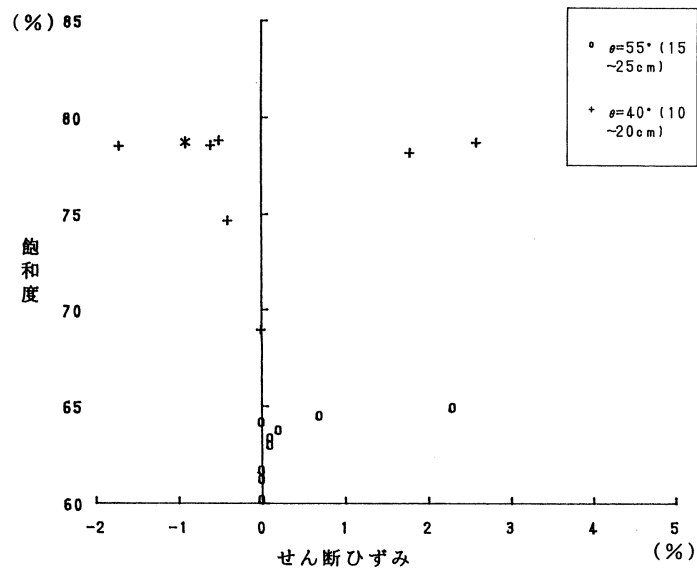

図ー9 地表面勾配の異なる場合のせん断ひずみ一飽和度

Fig. 9 Comparison of the relationships between shear strain and saturation ratio under different slope gradient

\section{表-1 三軸圧縮試験の試験条件}

Table 1 Experimental conditions of the triaxial compression test

\begin{tabular}{ll|l}
\hline \hline 飽和度 & $S r(\%)$ & $26.8,55.2,66.8,82.8,96.2$ \\
\hline 側 圧 & $\sigma_{3}\left(\mathrm{kgf} / \mathrm{cm}^{2}\right)$ & $0.1,0.2,0.3,0.4$ \\
\hline 乾燥密度 & $\rho_{d}\left(\mathrm{gf} / \mathrm{cm}^{3}\right)$ & 1.350 \\
(間隌比) & $(\mathrm{e})$ & $(0.997)$ \\
\hline
\end{tabular}

求めた。なお応力及びひずみについては，一般的に軸対 称応力状態に用いられる正八面体面上の表現 ${ }^{10)}$ とし, 主 応力差・偏差ひずみをそれぞれせん断応力・せん断ひず みに相当すると考えた。よって応力・ひずみは以下の式 により求めた ${ }^{10)}$ 。 


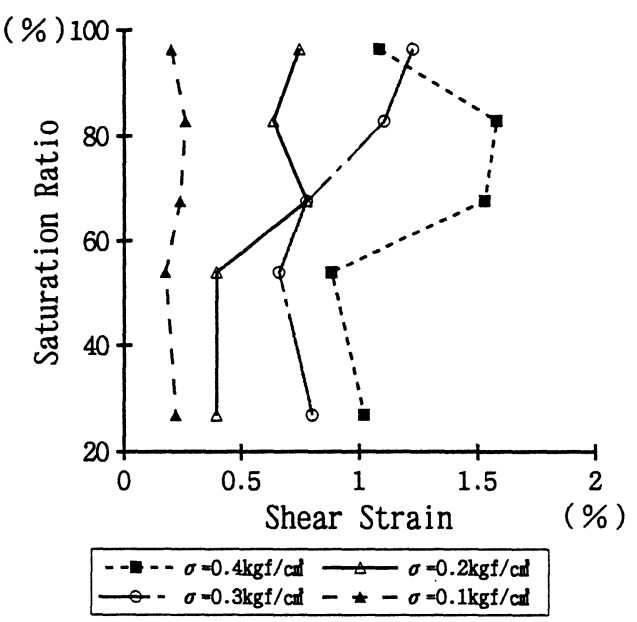

(a) 応力比 $z=1.2$ の場合

(a) Stress ratio $z=1.2$
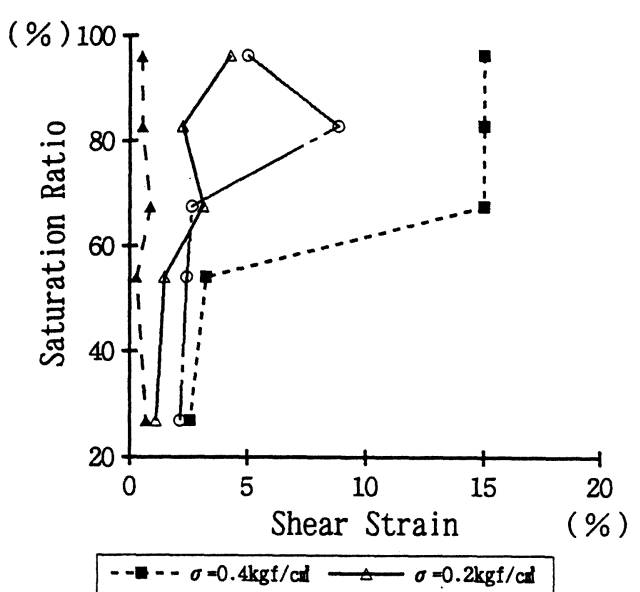

- $\sigma=0.3 \mathrm{kgf} / \mathrm{cull}- \pm-\sigma=0.1 \mathrm{kgf} / \mathrm{cm}$

(b) 応力比 $z=1.5$ の場合

(b) Stress ratio $z=1.5$

図-10 三軸圧縮試験における異なる側圧 $\sigma_{3}$ でのせん断ひずみ一飽和度の比較

Fig. 10 Comparison of the relationships between shear strain and saturation ratio under different $\sigma_{3}$ in the triaxial compression test

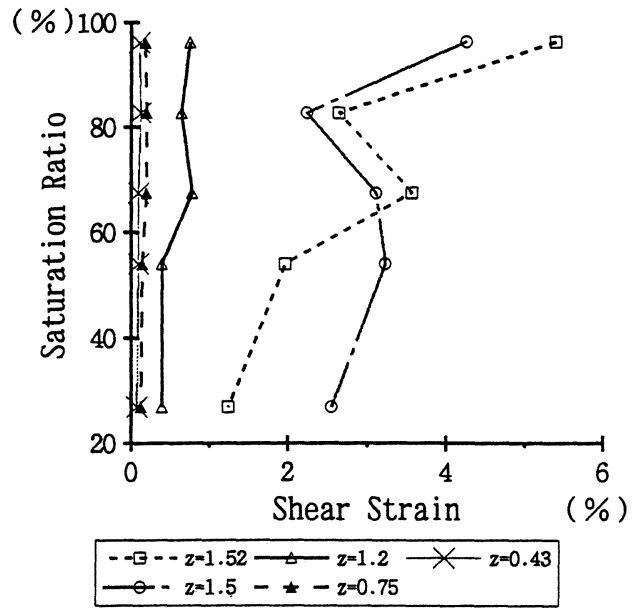

(a) 側圧 $\sigma_{3}=0.2 \mathrm{kgf} / \mathrm{cm}^{2}$ の場合

(a) $\sigma_{3}=0.2 \mathrm{kgf} / \mathrm{cm}^{2}$

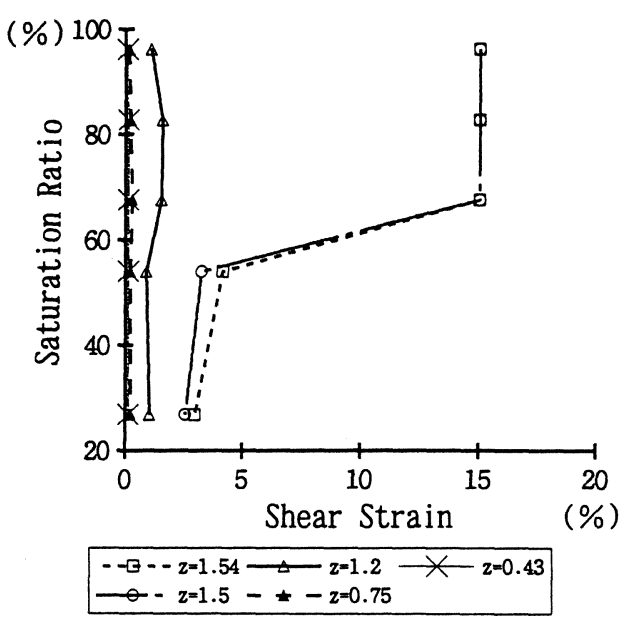

(b) 側圧 $\sigma_{3}=0.4 \mathrm{kgf} / \mathrm{cm}^{2}$ の場合

(b) $\sigma_{3}=0.4 \mathrm{kgf} / \mathrm{cm}^{2}$

\section{図-11 三軸圧縮試験における異なる応力比でのせん断ひずみ一飽和度の比較}

Fig. 11 Comparison of the relationships between shear strain and saturation ratio under different stress ratio in the triaxial compression test

平均主応力: $p=(1 / 3)\left(\sigma_{1}+2 \sigma_{3}\right)$

主 応力 差: $q=\sigma_{1}-\sigma_{3}$

応力 比: $z=q / p$

せん断ひずみ: $\varepsilon_{d}=(2 / 3)\left(\varepsilon_{1}-\varepsilon_{3}\right)$

応力については, 全応力表示とし, ひずみについても 弾性成分と塑性成分を分離せずに全ひずみで表した。

以下に解析結果について述べる。

(1)側圧を変化させた時のせん断ひずみ一飽和度
図-10 の (a) が応力比 $z=1.2$ の場合, 同 (b) が $z=$ 1.5 の場合である。また側圧と応力比が一定であれば, 式 (1) (3) より平均主応力が一定であることになる。図 (a) の応力比が小さい場合は実験誤差等の影響が大きくはっ きりしないが, 図 (b) のように応力比が大きい場合は, 基 本的には側圧つまり平均主応力が大きいほど, 同じ飽和 度でもせん断ひずみは大きく, またその傾向は飽和度が 大きくなる程顕著になるようである。側圧の小さい状態 では, 飽和度が変化してもせん断ひずみの変化は小さい。 
つまり両者の関係は, 応力比が大きいほど双曲線関係に 近づき, かつこの曲線は側圧が大きいほど右方へシフト すると考えられる。ちなみに図(b) のせん断ひずみが 15\%の場合は, その条件下での応力はピーク強度以上で あること，つまり破壊した状態であることを示す。

また図ー10において, 全体的な傾向とは逆に, 飽和度 の上昇につれてせん断ひずみが減少している場合が局所 的にある。これは三軸圧縮試験は飽和度一定及び側圧一 定の供試体の応力比を増加させて行ったが, 図ー10のせ ん断ひずみ一飽和度（側圧, 応力比一定）の関係は, 異 なる飽和度の供試体の試験結果を組み合わせて求めたた め, 各試験毎の実験誤差が図上に現れたものと考えられ る。

(2)応力比を変化させた時のせん断ひずみ一飽和度

側圧 $\sigma_{3}=0.2\left(\mathrm{kgf} / \mathrm{cm}^{2}\right)$ の場合を図-11(a)に, $\sigma_{3}=$ $0.4\left(\mathrm{kgf} / \mathrm{cm}^{2}\right)$ の場合を同 (b) に示す。側圧の大きい図 (b) の場合を見ると, 応力比が大きいほど同じ飽和度でのせ ん断ひずみが大きく，かつその傾向は飽和度が高くなる ほど顕著になる。応力比の小さい状態では, 飽和度が変 化してもせん断ひずみの変化は小さい。つまり側圧が大 きいほどせん断ひずみと飽和度の関係は双曲線関係に近 づき, 応力比が大きくなるほど全体的にせん断ひずみの 大きな右方の領域へ移行するようである。図(b)でせん断 ひずみが 15\%の場合は，上記(1)と同様に，その条件下で の応力はピーク強度以上であることを示す。

図-11でも局所的なせん断ひずみと飽和度の関係の 逆転が図上に認められるが,これも図 -10 と同様に各応 力比のせん断ひずみ一飽和度の関係が異なる試験結果を 組み合わせて求められたために，実験誤差が現れたもの と考えられる。

\section{3 崩壊実験と三軸圧縮試験での土の変形挙動の比較}

2.3 で示した崩壊実験での模型斜面内の土の不飽和状 態の変形挙動と, 3.2 で示した三軸圧縮試験での不飽和 試料の変形挙動の比較を行う。

(1)せん断ひずみ一飽和度の関係

せん断ひずみと飽和度の関係については, 模型斜面内 の土の挙動(例えば図-7)も, 三軸圧縮試験でのそれ(例 えば図-10(b)）も，基本的には飽和度が大きくなるとせ ん断ひずみも大きくなる傾向がある。また崩壊実験では 必ず破壊領域までせん断ひずみが達しているので, 両者 の関係はある飽和度に漸近するにつれてせん断ひずみが 無限大となっていくという双曲線関係に近似されうる。 三軸圧縮試験についても破壊領域に達したもののみ見る と, 同様に双曲線関係を示すと考えて良いと思われる。

しかし崩壊実験の方が初めてせん断ひずみが確認され る飽和度と, せん断ひずみが無限大状態になるときの飽 和度が大きく, 双曲線が飽和度の大きい領域に存在する。
前者については, 崩壊実験での測定精度が悪いために飽 和度の小さい状態での微少なせん断ひずみが計測できて いないためと考えられる。またせん断ひずみも全体的に 崩壊実験の方がやや小さい值をとっている。これについ ては, 例えば崩壊実験では主応力軸が回転する単純せん 断 ${ }^{11)}$ が斜面内で進行し, 後者の三軸圧縮試験では主応力 軸が固定されているなどの, せん断メカニズムの相違に よることや，崩壊実験では非常に拘束圧の小さな状態で せん断が進行していることなどによるものと考えられる。 (2)拘束圧を変化させた時のせん断ひずみ一飽和度

崩壊実験については図 -8 に垂直応力を変化させた時 のせん断ひずみと飽和度の関係を, 三軸圧縮試験につい ては図ー10に側圧 (平均主応力) を変化させた時のせん 断ひずみと飽和度の関係を示している。

崩壊実験では垂直応力が大きくなるにつれて同一のせ ん断ひずみに達する時の飽和度が大きくなるが, 三軸圧 縮試験では逆に側圧（平均主応力）が大きいほど同一の せん断ひずみに達する時の飽和度が小さくなる。つまり 拘束圧が大きくなると, 崩壊実験では双曲線が飽和度の 大きな領域に移動するが, 三軸圧縮試験では逆に飽和度 の小さな領域に移動する。

(3)応力比を変化させた時のせん断ひずみ一飽和度 崩壊実験において応力比は斜面傾斜に相当すると考え られる。図 -9 は崩壊実験で表面傾斜の異なる場合のせ ん断ひずみと飽和度の関係を比較したものである。また 三軸圧縮試験については図一11に異なる応力比のせん 断ひずみと飽和度の関係を比較している。

崩壊実験では表面勾配の大きな方が飽和度の小さい領 域でせん断ひずみが進行している。また三軸圧縮試験で も応力比の大きい方が同一のせん断ひずみに達する飽和 度が小さくなっている。つまり両実験での土の挙動は合 致している。

\section{4. 結 論}

急勾配斜面の不飽和状態での崩壊発生機構を解明する ための第一歩として, 崩壊実験を行い飽和度が増加する 時の斜面内の土のせん断の進行について検討した。その 結果以下のような結果が得られた。

(1)飽和度が大きくなるにつれてせん断ひずみが増加し， ある飽和度に近づくとせん断ひずみが無限大になるよ うな双曲線関係をせん断ひずみと飽和度の間に確認し た。

(2)垂直応力が大きいほど, 上記の双曲線関係は飽和度 の大きな領域で進行することが確認された。

(3)地表面傾斜が大きいほど, 飽和度の小さい領域でせ ん断が進行することが確認された。

そして飽和度を変化させた試料を用いた三軸圧縮試 
験を行い，飽和度とせん断ひずみの関係について検討 し, 崩壊実験結果と比較した。その結果以下の事項が 判明した。

(4)三軸圧縮試験においても，飽和度が増加すると，せ ん断ひずみも増加するという基本的な関係が確認され た。特に飽和度が大きい領域で破壞状態に達するよう な場合は，崩壊実験と同様にせん断ひずみと飽和度の 間の双曲線関係が確認された。

(5)応力比が大きいほど，また拘束圧が大きいほど飽和 度の小さい領域でせん断は進行する。崩壊実験につい て地表面傾斜を応力比に読み換えると，この三軸圧縮 試験結果と合致するが，垂直応力を拘束圧に読み換え た時の崩噮実験の結果は三軸圧縮試験の結果と逆の傾 向を示した。

以上の結果より，急勾配斜面内の土の不飽和状態での せん断（単純せん断）の進行は，単純せん断と軸対称状 態のせん断という異なるメカニズムの下での応力・ひず みを統一的に表現できれば，基本的には三軸圧縮試験で 求められる飽和度とせん断ひずみの関係で説明しうると 考えられる。しかし拘束圧の変化に関する飽和度とせん 断ひずみの挙動が逆の傾向を示した。この点についてさ らに検討を深める必要がある。

\section{参考文献}

1 ）矢澤昭夫他: 平成 5 年 7 9 月の鹿児島災害調査速報, 土 木技術資料, Vol. 36, No. 2, 1994.2

2 ) 吉松弘行 ・三井宏人: がけ崩れ災害の実態, 土木研究所資 料第 2583 号, p. 70 , 昭和 63 年 2 月

3 ) 三森利昭他: 人工降雨による室内崩壊実験 (I) 一 予備実 験一, 平成 3 年度砂防学会研究発表会概要集, pp. $272 \sim 275$, 平成 3 年 5 月

4) 土屋智: まさ土と川砂の模型斜面を用いた降雨浸透時の 崩壊発生機構について, 平成 4 年度砂防学会ワーク ショップ研究成果報告書「崩壊機構の実験的研究の現状 と今後の課題」, pp. $9 \sim 18,1993.3$

5 ) 工藤賢二他: 斜面崩壊前兆現象計測のための基礎実験, 平成 2 年度砂防学会研究発表会概要集, pp. 354 357, 平 成 2 年 5 月

6 ）風間秀彦・芥川真知・滝沢太郎: 降雨に伴う砂質土の強度 低下と斜面の不安定化, 不飽和土の工学的性質研究の現 状シンポジウム発表論文集, pp. 267〜 274, 1987.12

7 ）海老原和重・笹原克夫・綱木亮介: 急勾配斜面の不飽和条 件下での変形に関する検討, 平成 6 年度砂防学会研究発 表会概要集, pp. 91 94, 平成 6 年 5 月

8 ）海老原和重・笹原克夫・綱木亮介: 砂質斜面の不飽和条件 における変形特性の検討, 第 33 回地すべり学会研究発表 講演集, p. $359 \sim 362$, 平成 6 年 8 月

9）土質工学会: 土質試験の方法と解説, p. 376 , 平成 2 年 3 月

10) Schofield, A. N. and Wroth, C. P.: Critical State Soil Mechanics, McGraw-Hill, London, 1968

11) Cole, E. R. L.: The Behaviour of Soils in the Simple Shear Apparatus, Ph. D Thesis at Cambridge Univ., 1967 